\title{
Influence of Micro Climatic Indices on Growth and Yield of Direct Seeded Upland Rice (Oryza sativa L.) Varieties in Assam
}

Bidisha Borah, Kalyan Pathak

10.18805/ag.R-2404

\begin{abstract}
Background: Rice (Oryza sativa L.) is the major cereal crop grown in India. Rice plays a pivotal role in the socio-cultural life of the people of Assam. The main objective of this study to investigate the influence micro climatic indices in relation to crop growth and yield of upland rice varieties with different dates of sowing in Assam.

Methods: A field experiment was carried out at Instructional cum Research Farm, Assam Agricultural University, Jorhat during autumn season of 2017. The experiment consisted of four micro-climatic regimes (M) along with four different rice varieties (V).

Result: The results of the experiment revealed that micro climatic indices viz., canopy temperature, growing degree days, soil moisture content, soil temperature, light intensity, depth of ground water table associated with $1^{\text {st }}$ April sown crop recorded positive effect on growth and yield parameters in terms of plant height, leaf area index, number of filled grains per panicle, test weight, harvest index and grain yield ( $3004 \mathrm{~kg} / \mathrm{ha}$ ), followed by the micro-climate associated with $16^{\text {th }}$ March sown crop. Among the varieties evaluated, CR-Dhan 203 recorded the highest grain yield of $2860 \mathrm{~kg} / \mathrm{ha}$ and was significantly superior to that of other varieties except Inglongkiri.
\end{abstract}

Key words: Canopy temperature, Growing degree days, Leaf area index, Light intensity, Seeding date, Soil temperature.

\section{INTRODUCTION}

Rice is one of the chief grains of India. Rice consumes much more water than other cereals and nearly 3000-5000 liters of water is required to produce one kilogram of rice (Bouman, 2009). Among many food grains produced in India, rice has the pride of being cultivated over an area of 44.40 million hectare with a production of 109.32 million tones and average productivity is $2.27 \mathrm{t} / \mathrm{ha}$ (Agricultural Statistics, 2016). Assam is traditionally a rice growing state. Rice plays a pivotal role in the socio-cultural life of the people of the state. In Assam, rice is cultivated in 2.48 million hectare with a production of 5.12 million tones and productivity of $2.08 \mathrm{t} / \mathrm{ha}$ varying with districts and agro-climatic zones (Statistical Handbook of Assam, 2016). The state has its climatic and physiographic features favorable for rice cultivation and the crop is grown in a wide range of agroecological situations. Rice is cultivated in three distinct seasons in Assam viz., ahu or (autumn rice) (grown during February/March-June/July), Sali or (winter rice) (grown during June/July-November/December) and boro or (summer rice) (grown during November/December-May/ June). Ahu or autumn rice is grown mostly aerobically in upland areas and it covers around 1.9 lakh hectares, production is 2.5 lakh tones with average productivity of 1.32 t/ha (Agricultural Statistics, 2016). This system of rice cultivation saves water by eliminating wetland preparation necessary to avoid seepage and percolation and by reducing evaporation. This crop has certain advantages; for example, the utilization of solar energy is more efficient as most of the time in this season, the sky remains clear and this crop normally escapes the risk of flood damage which is very important in flood prone areas. Aerobic rice is a production system in which potentially high yielding, fertilizer responsive
Department of Agronomy, Assam Agricultural University, Jorhat785 013, Assam, India.

Corresponding Author: Bidisha Borah, Department of Agronomy, Assam Agricultural University, Jorhat-785 013, Assam, India.

Email: bidisha.borah@aau.ac.in

How to cite this article: Borah, B. and Pathak, K. (2022). Influence of Micro Climatic Indices on Growth and Yield of Direct Seeded Upland Rice (Oryza sativa. L) Varieties in Assam. Agricultural Reviews. DOI: 10.18805/ag.R-2404.

Submitted: 09-10-2021 Accepted: 09-02-2022 Online: 03-03-2022

rice varieties are grown in fertile aerobic soils that are nonpuddled and have no standing water. Supplementary irrigation, however, can be given in the same way as to any other upland cereal crop (Wang et al., 2002). Since rice is the major consumer of fresh water, it also leads to destruction of soil aggregates, nutrient losses through leaching. To make paddy cultivation cost effective and eco-friendly, direct seeded rice provides an option which save not only labor required for seedling raising in the nursery, uprooting and transplanting of seedlings but also helps to preserve natural resources especially underground water. However, to make this technology viable, proper micro-climate through appropriate sowing time of suitable varieties needs to be identified for various agro ecological conditions. Considering the above facts, the experiment was carried out to find out optimum microclimate regimes for different promising varieties of rice for realizing higher yields under aerobic condition.

\section{MATERIALS AND METHODS}

A field experiment was conducted at the Instructional cum Research (ICR) Farm of Assam Agricultural University, 
Jorhat, Assam during autumn season of 2017 on performance of different rice varieties grown at different dates of sowing in relation with crop growth, yield and micro climatic indices. The experiment was laid out in split plot design tested with three replications having plot size of $4 \times 3$ $\mathrm{m}^{2}$. The experiment was comprised of sixteen treatment combinations, viz., four micro-climatic regimes (M) ( $M_{1}$ : $15^{\text {th }}$ February, $M_{2}: 1^{\text {st }}$ March, $M_{3}: 16^{\text {th }}$ March and $M_{4}: 1^{\text {st }} A$ pril) assigned in main plots and four varieties $(V)\left(V_{1}: C R-\right.$ Dhan 205, $V_{2}$ : CR-Dhan 203, $V_{3}$ : CR-Dhan 204 and $V_{4}$ : Inglongkiri) were in sub-plots. All the production practices were followed as per Assam Agricultural University, Jorhat recommendation for the state. The soil of the experimental field was sandy loam in texture, acidic in reaction $(\mathrm{pH}: 5.2)$, medium in organic carbon content $(0.62 \%)$, medium in available nitrogen $(311.5 \mathrm{~kg} / \mathrm{ha})$, low in phosphorus (15.85 $\mathrm{kg} / \mathrm{ha}$ ) and medium in available potassium (194.0 kg/ha). The climatic condition of Jorhat is humid sub-tropical with hot summer and cool winter. The weather parameters viz., mean maximum and minimum temperature, mean relative humidity, mean daily sun shine hours, evaporation and weekly total rainfall were recorded at Agro-meteorological observatory of Assam Agricultural University, Jorhat and presented in Fig 1. The micro climatic indices like canopy temperature, growing degree days, light intensity, soil moisture content, soil temperature, depth of water table and crop growth and yield attributes like plant height, leaf area index, number of filled grains per panicle, test weight, harvest index and grain yield were recorded and statistically analyzed at $5 \%$ level of significance. The cost of cultivation, net returns and $B: C$ ratios were worked out based on the prevailing local market price.

\section{RESULTS AND DISCUSSION}

\section{Influence of sowing dates on micro climatic indices}

Plants respond to the climate where they are growing. Micro climate refers to the climatic conditions of a small, specific place, where conditions may differ from those of the larger surrounding space. Three main parameters to define a microclimate within a crop environment are temperature, humidity and sunshine hours (Jagadish et al. 2017).

Different sowing dates significantly influenced the canopy temperature at all the growth stages of the crop (Fig 2). The highest values were recorded on $1^{\text {st }}$ April sown crop. During the entire crop growth period $1^{\text {st }}$ April received less stress condition as compared to the other sowing dates and this might be due to difference between ambient temperature and canopy temperature were in the range of 3 to $5.75^{\circ} \mathrm{C}$ and among which the $1^{\text {st }}$ April sown recorded the lowest range $\left(3\right.$ to $\left.5.4^{\circ} \mathrm{C}\right)$. The trend in the deviation of canopy temperature from ambient temperature indicated better. Therefore, $1^{\text {st }}$ April sown crop resulted higher in growth and yield attributing characters, this might be due to activation of some enzyme under favourable canopy temperature such as sucrose phosphate synthase, which helps in grain filling process and ultimately helps in increasing the yields.

Growing degree days were more in $1^{\text {st }}$ April sown crop (Fig 3), which means $1^{\text {st }}$ April sown absorbed more heat units than other sowing dates. This might be due to $1^{\text {st }}$ April sown crop received more number of degree days to complete its growing period. Due to delay in sowing from $15^{\text {th }}$ February to $1^{\text {st }}$ April, the heat units increased gradually throughout the growing period.

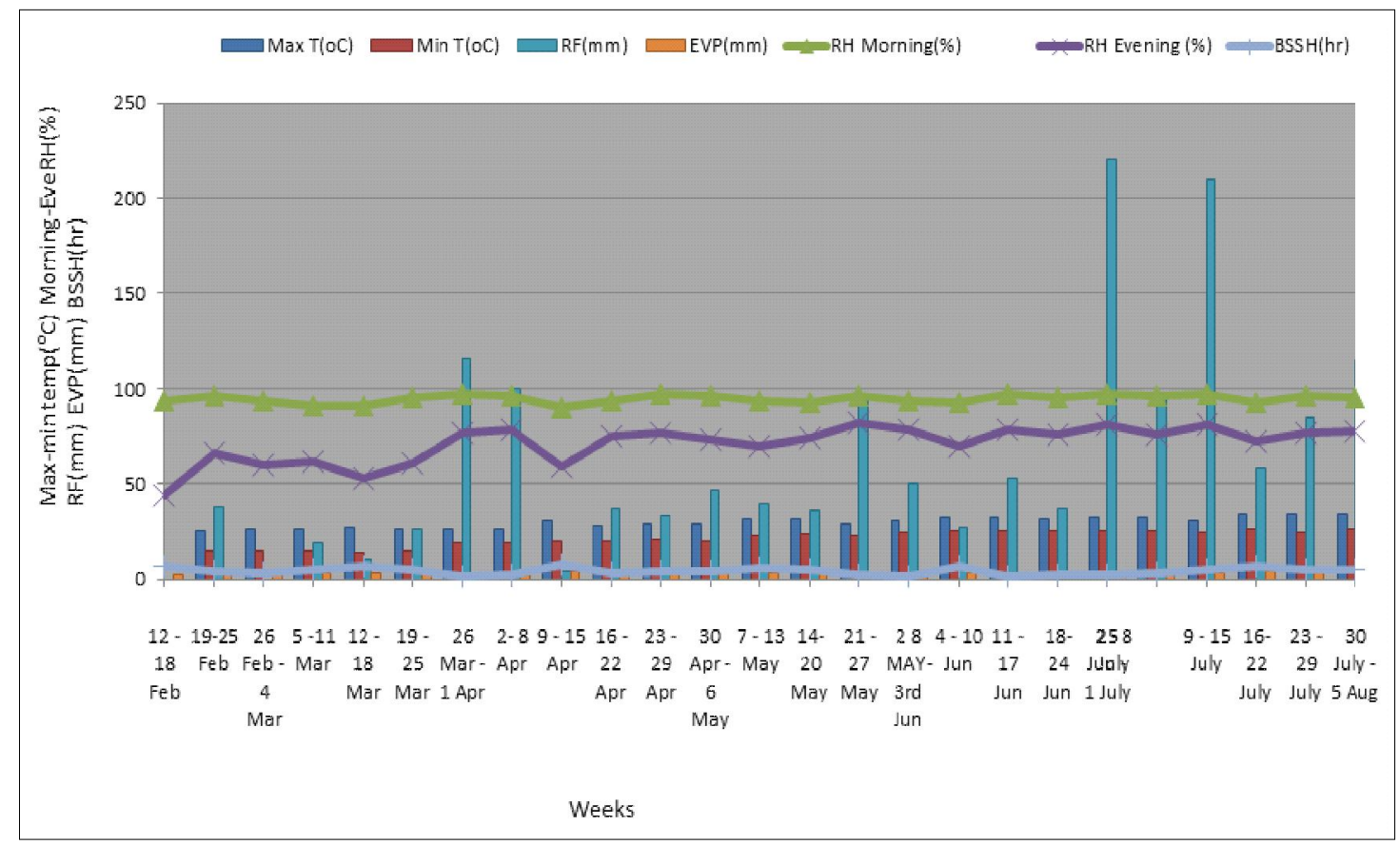

Fig 1: Graphical representation of the weekly meteorological data observed during the crop growth period. 
The morphological, physiological and yield parameters of rice have showed variation due to differed light intensity among the different date of sowing where $1^{\text {st }}$ April sown crop recorded high light intensity and thus lead to higher photosynthesis which helped in increasing the crop growth and yield (Fig 4). Murty et al. (1976) amply demonstrated that the movement of photosynthates to aerial part was enhanced under lower light intensity but the available photo assimilates was low due to impaired photosynthesis under reduced light intensity. The high light resulted in grain filling by increasing the number of spikelets.

Soil moisture and temperature are the important climatic parameter for better growth of a crop. These two parameters are interrelated. At a very low soil temperature, moisture intake by crop stops. Soil moisture and temperature influence the germination of seeds. Excessively high amount is harmful to roots and extreme low amounts decrease nutrients uptake and also extreme low values influences the soil microbial population and rate of organic matter decomposition (Yoshida et al., 2007). A very high soil temperature of more than $35^{\circ} \mathrm{C}$ during tillering to panicle initiation would affect the grain filling process in addition to the grain setting process. A high soil temperature before the heading stage would significantly affect the grain filling (Sato et al., 1973; Kobata et al., 2004). In rice, photo synthesis decreases when temperarture is more than $35^{\circ} \mathrm{C}$ at the later ripening stage, while grain filling is insensitive to high root temperature. The adverse effect of extreme soil temperature during ripening on grain filling would be more prominent if the sink demand were large, as in the case of

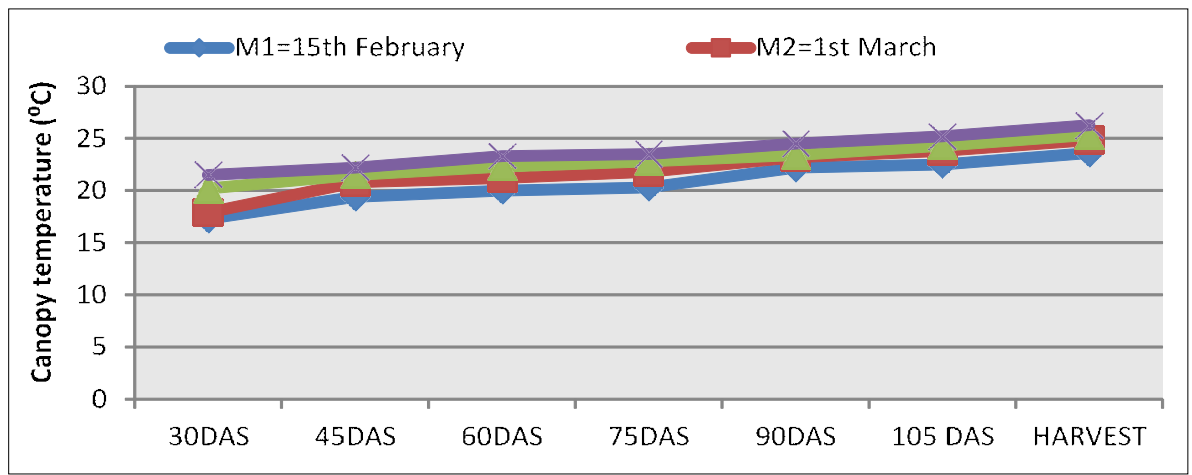

Fig 2: Canopy temperature influenced by different dates of sowing.

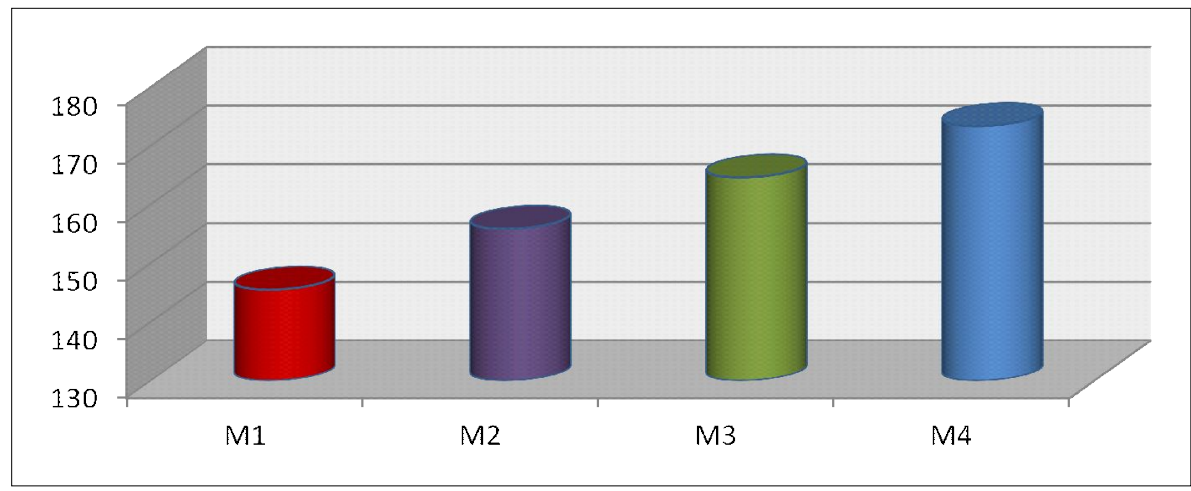

Fig 3: Effect of date os sowing on GDD of aerobic rice.

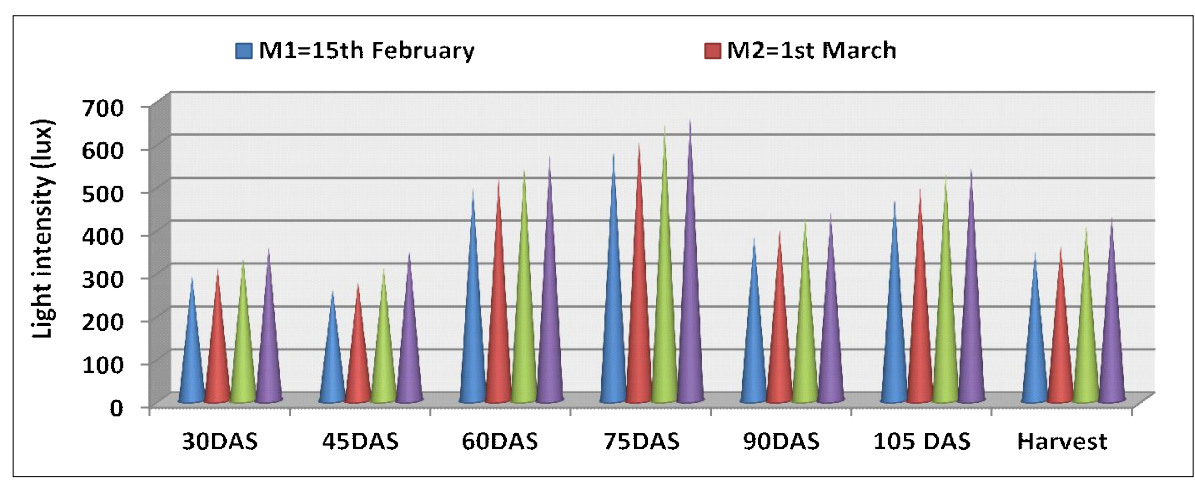

Fig 4: Light intensity influenced by different dates of sowing. 
high spikelet numbers (Sanoh et al.,2010). Results of this study revealed that $1^{\text {st }}$ April sown crop recorded higher productivity due to the favourable soil temperature $\left(21-30^{\circ} \mathrm{C}\right)$ during the growth period up to harvest of the crop (Fig 5, 6).

\section{Influence of sowing dates and varieties on growth parameters}

The growth parameters recorded periodically have showed variations due to different micro-climatic regimes and varieties. Plant height at all the growth stages was not influenced by different dates of sowing, however, $1^{\text {st }}$ April sown crop recorded higher values. High rainfall during the growth period on April $1^{\text {st }}$ sown crop during its vegetative growth might have increased the height. Among the varieties tested, highest plant height at all the growth stages was recorded in Inglongkiri which might be due to the genetic character of the variety (Table 1) as plant height depends on genetic makeup of a plant and environmental conditions. A similar findings was reported by Asif et al. (2014), Ramachandra et al. (2015) and Kannan et al. (2015). Leaf Area Index was recorded highest in $1^{\text {st }}$ April sown crop and sowing date significantly affected this physiological parameter. Tiwari (2015), found that time of sowing in paddy crop is utmost importance due to variation in duration and climatic condition of the area.The leaf area index was also found to be significantly affected by different rice varieties. Highest LAI was observed in case of rice variety CR-Dhan 203. The variation in LAl among rice varieties might be due to the variation in genetical characteristics among the varieties (Table 1).

\section{Influence of sowing date and varieties on yield attributes and yield}

The yield attributes are the most important parameters of any crop which directly influence the crop yield. These yield attributes and yields are likely deviate up to considerable extent as a result of variability in the crop management practices for increased crop production.

The number of filled grains/panicle showed a better response with delay in sowing because in early sowing the plants might have suffered from unfavourable temperature which ultimately resulted in shedding of pollen; therefore, reduced the number of filled grains/panicle and ultimately the grain yield (Table 1). This might be attributed to better plant growth leading to significantly more number of filled grains/panicle and better partitioning of photosynthesis compared to other sowing dates. Moreover, due to favourable climatic condition such as optimum temperature (23 to $\left.30^{\circ} \mathrm{C}\right)$, average weekly rainfall $(76.8 \mathrm{~mm}$ ) might have resulted in higher uptake of nutrients as well as post photosynthetic contribution in respect to other sowing dates. Similar, findings were reported by Khalifa 2009), Dawadi and Chaudhary (2013), Sidhu et al. (2014) and Sivapalan (2014). Different rice varieties significantly affected the yield attributing characters of rice. Rice variety CR-Dhan 203 produced significantly higher number of grains/panicle which

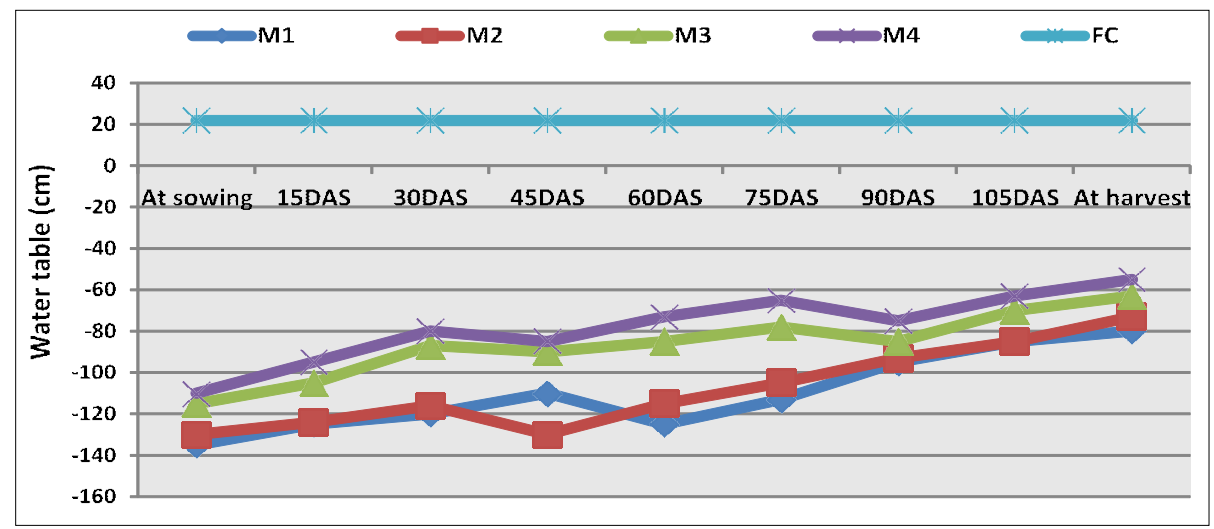

Fig 5: Water table status through out the experimentation.

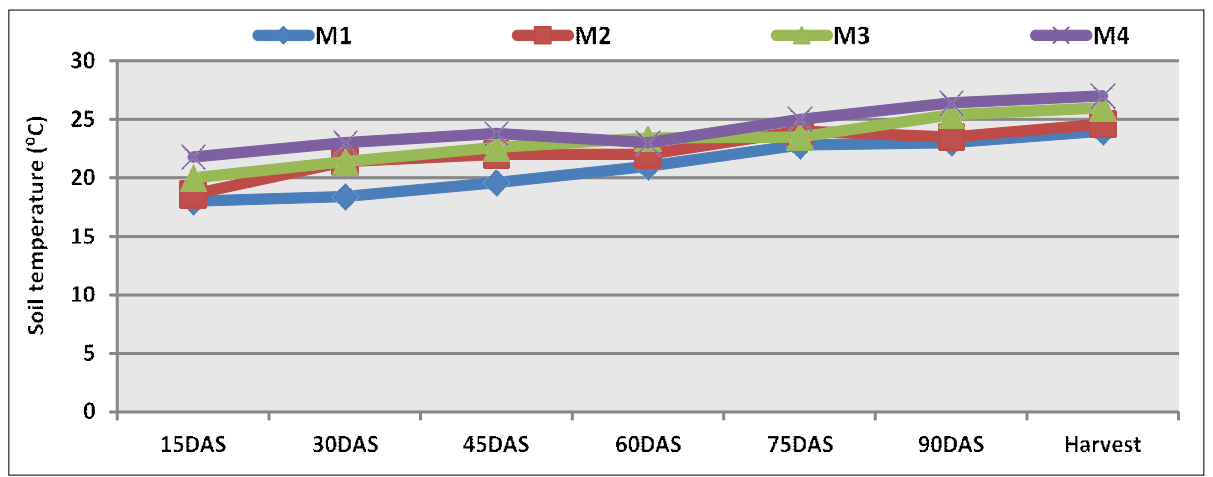

Fig 6: Soil temperature at $0-15 \mathrm{~cm}$ depth through out the experimentation. 
was followed by variety Inglongkiri and this is probably due to more effective tillers $/ \mathrm{m}^{2}$ and higher length of panicle exhibited by CR-Dhan 203 over rest of the varieties and also might be due to variation in genetical character of the variety. The significant differences in yield attributes among the rice varieties have also been reported by Brar and Bhullar (2013), Dawadi and Chaudhary (2013), Ramachandra et al. (2015), Kumar et al. (2015) and Tiwari (2015). The crop sown on $1^{\text {st }}$ April produced higher values in all the attributes and yield followed by $16^{\text {th }}$ March sown crop. This might be due to high light intensity amount in the micro-climatic regime. The variety CR-Dhan 203 resulted in highest grain yield. This might be due to the higher value of yield attributing characters and genetic yield potential of the rice variety in aerobic condition (Table 1 ).

\section{Influence of dates of sowing and varieties on economic indices}

Relatively late sowing positively influenced the yield and thereby net income in the experiment. Among the microclimatic regimes, the $1^{\text {st }}$ April sown crop of aerobic rice gave the highest net income (Rs. 51755.36 /ha) and a B- C ratio (2.3) andthis might be due to higher yield. CR-Dhan 203 proved its superiority by giving highest net income (Rs. $46865.01 /$ ha) and a $B: C$ ratio (2.04) followed by Inglongkiri. This is attributed to net income in relation to the crop productivity and the gross income received. The increase in net income and benefit-cost ratio might be due to positive effect of the treatments on growth and yield attributes results in higher grain and straw yield (Table 1).

\section{CONCLUSION}

All the micro climatic indices associated with $1^{\text {st }}$ April sown crop positively influenced the crop growth and yield followed by mid March sown crop. Treatment combination of crop sown on $1^{\text {st }}$ April with variety CR-Dhan 203 recorded the highest net return and $B: C$ ratio.

\section{ACKNOWLEDGEMENT}

The author duly acknowledges the co-operations received from Assam Agricultural University, authority particularly Department of Agronomy and Directorate of Post Graduate Studies during the experimentation period.

\section{Conflict of interest: None.}

\section{REFERENCES}

Agriculture Statistics of India, 2016.

Asif, A., Aslam, Z., Zaman, Q., U., Ehsanullah.,Zamir, S.I., Khan, I. and Subhani, M.J. (2014). Performance of different cultivars in direct seeded rice (Oryza sativa L.) with various seeding densities. American Journal of Plant Sciences. 5: 3119-3128.

Bouman, B.A.M. (2009). How much water does rice use. Rice Today. 8: 28-29.

Brar, H.S. and Bhullar, M.S. (2013). Nutrient uptake by direct seeded rice and associated weeds as influenced by sowing date, variety and weed control. Indian J. Agric. Res. 47(4): 353-358.
Dawadi, K.P. and Chaudhary, N.K. (2013). Effect of sowing dates and varieties on yield and yield attributes of direct seeded rice in Chitwan, Nepal. International Journal of Agricultural Science Research. 2(4): 192-201.

Jagadish, K.S.V., Yadav, S., Faronilo, J., Mattes, N. and Quinones, C. (2017). Drought stress reduces grain yield by altering floral meristem development and sink size under dryseeded rice cultivation. Crop Science Society of America. 57: 313-332.

Kannan, K., Kundu, D.K., Singh, R., Thakur, A.K. and Chaudhari, S.K. (2015). Productivity and water use efficiency of aerobic rice under differentmoisture regimes in Eastern India. Indian Journal of Soil Conservation. 43(2): 170-174.

Khalifa, A.A.B.A. (2009). Physiological evaluation of some hybrid rice varieties under different sowing dates. Australian Journal of Crop Science. 3(3): 178-183.

Kobata, T., Uemuki, N.,Inamura T. and Kagata, H. (2004). Shortage of assimilate supply to grain increases the proportion of milky white rice kernels under high temperatures. Jpn J. Crop Sci. 73: 315-322.

Kumar, A., Manuja, S. and Shekhar, J. (2015). Performance of rice (Oryza sativa L.) varieties under aerobic cultivation in mid hills of Himachal Pradesh. Himachal Journal of Agricultural Research. 41(2): 160-162.

Murty, K.S., Nayak, S.K., Sahu, G., Ramakrishnayya, G., Jonardhan, K.V. and Rai, R.S.V. (1976). Efficiency of 14C photo synthesis and translocation in local and high yielding rice varieties. Plant Biochemistry J. 3: 63-371.

Ramachandra, N., Ningaraju, G.K., Shivakumar, M., Rajanna, P. and Krishnamurthy, R. (2015). Studies on response of varieties and different dates of sowing on productivity of aerobic rice. Rice Research. pp. 2375-4338.

Sanoh, A.Y., Ishimaru, T., Ohsumi, A. and Kondo, M. (2010). Effects of Soil Temperature on Growth and Root Function in Rice. Plant Prod. Sci. 13(3): 235-242.

Sato, K.,Inaba, K. and Tozawa, M. (1973). High temperature injury of ripening in rice plant. II. Ripening of rice grains when the panicle and straw were separately treated under different temperature. Proc. Crop Sci. Soc. Japan. 42: 214-219.

Sidhu, A.S., Walia, U.S.,Walia, A.S. and Nayyar, S. (2014). Productivity of direct seeded rice in relation to different dates of sowing and varieties in Central Punjab. Journal of Crop and Weed. 10(1):126-129.

Sivapalan, S. (2014). Effect of planting date on grain yield of selected rice cultivars grown in the Ord. Crop Updates. 3.

Statistical Handbook of Assam, (2016). Directorate of Economics and Statistics Government of Assam, Guwahati-28.

Tiwari, P. (2015). Effect of sowing-dates on performance of different rice varieties under upland condition. M.Sc Thesis, College of Agriculture, Rewa.

Wang, H., Bouman, B.A.M., Zhao, D.,Wang, C. and Moya, P.F. (2002). Aerobic rice in northern China: Opportunities and challenges in B A m, water wise rice production. IRRI, Los Banos, Philippines. Pp 143-154.

Yoshida, T., Tong, L., Maeda, T. and Kimijima, H. (2007). Effects of temperature, sowing depth and soil hardness on deedling establishment and yield of cambodian rice direct-seeded in flood paddy fields. Plant Prod. Sci. 10(1): 129-135. 